\title{
Classroom discussions: Possibilities and limitations for democratic classroom practices
}

\author{
Turid Skarre Aasebø ${ }^{1}$
}

\begin{abstract}
Are students offered possibilities to experience democratic practice in classrooms? Using an analysis of empirical data from classroom discussions in lower secondary school, this article identifies and explores two different types of classroom discussions which give students different positions: a conversation in which students are positioned as 'poll respondents', and a more deliberative conversation which positions students as learning debaters. The two forms of classroom discussions are discussed due to the way they give different meaning to democracy, and due to whether the student positions in the classrooms imply contribution to the subject matter and what is considered valuable knowledge in school.
\end{abstract}

Keywords: democracy, student position, classroom discussion, deliberative communication,

\section{Introduction}

Democratic participation and democratic citizenship are concepts which for years have been included in aims of education and are initiated by national education boards as well as from the Council of Europe. The formulated purposes of schooling include knowledge about democracy as well as participation in democratic processes (Meld. St. 20, 2012-2013).

Informing students about democratic values as opposed to developing democratic values and skills through experience has long been a debate in the tradition of democratic education. Biesta (2012), in line with many other researchers, has emphasised the necessity of learning and experiencing democracy instead of providing teaching in citizenship. The policy, practice and research focus must be on the students' 'participation in the contexts and practices that make up their daily lives in schools' (p. 6).

This leads to the question of whether students are offered possibilities to experience democratic values in classrooms, and what kind of democratic practice are involved in these experiences. While democratic practice in school contains different activities from student council work to students' influence in decision-making in classrooms, Stray (2012) has concluded from a Norwegian context that the concept of democracy is ambiguous and rarely discussed when it comes to the curriculum. The information and communication technology which according to Buckingham 'represent a significant means of "informal" political education (...) for young people' (2000, p. 173), obviously does not always involve knowledge, perspectives, and attitudes that shore up the school's content. In this respect the democratic practice in school should also deal with the subject matter in teaching; the knowledge. Accordingly, the question whether democratic experience also comprises the school's subject matter and challenges what knowledge is about or what counts as valuable knowledge will be raised. The keener focus on accountability, tests, and assessments of knowledge in this age does not make this question less relevant.

The focus on democratic practice in this article is on the communication between the teacher and students in plenary or whole-class talk which can be looked upon as a public space where everyday conversations/communication take place. Democratic experience is

\footnotetext{
${ }^{1}$ University of Agder, Norway, Turid.S.Aasebo [at] uia.no
} 
about students adopting positions in relation to the world (Englund, 2006), or taking up subject positions, which is the concept used in social constructionist theory. From a social constructionist point of view, the everyday conversation is an important arena 'far beyond the immediate social event' (Burr, 2003, p. 115). Everyday conversation represents an important arena in which we position ourselves and others in ways through which identities are fashioned and power relations played out' (p. 115).

Using qualitative data from classroom talk this article explores whether students are offered possibilities for democratic experience through the ways they are positioned in communication in plenary or whole-class discussions in classrooms. The different classroom discussions and student positions are identified and discussed due to how they give different meanings to democracy. Finally, it is discussed whether the classroom discussions in this study give students positions as valued contributors to subject matter, or not.

\section{Studies in democracy and classroom discussions}

There are numerous concepts of democracy, where a dividing line runs through emphasising individual rights and interests, and emphasising community and individual contributions to the community. The one model is described as a liberal and pluralistic tradition and deals with voting and voting order (Eriksen \& Weigård, 1999), and with the idea of self-determination related to one's own life as well as freedom from external forces (Solhaug \& Børhaug, 2012). This tradition, also known as competition democracy (Eriksen \& Weigard, 1999), is close to the perspective on the empowerment of citizens. The other model is described as a republic tradition and deals with participation and discussion which give the participants the opportunity to take a stance on issues (Eriksen \& Weigård, 1999). Democracy is looked upon as a common good that enlightens, informs and cultivates citizens. It deals with the formation of communities and solidarity (Solhaug \& Børhaug, 2012). Habermas has introduced a third model, deliberative democracy, which builds on communicative action theory (Habermas, 1996). Deliberative democracy involves giving reasons for statements and defending statements in discussions that can open for the possibility of making common standards, finding shared solutions and changing peoples' minds. Deliberative democracy is a procedural model which assumes the presence of autonomous actors who are able to give their free opinion in open and free communication (Eriksen \& Weigård, 1999).

Research on democratic experiences in the classroom touches on a number of fields, such as teachers' way of handling conflicts and controversies, equity in teachers' practice, students' involvement in daily decisions (informal influence), school democracy and student council work (formal influence), conversation culture and classroom discussions. This research includes experiments in taking stands and analysis of occurring conversations (Cazden, 2001; Fine, 1993; Liljestrand, 2002; Ekman, 2011; Solhaug \& Børhaug, 2012). Democracy is also linked to citizenship (Grant, 1996; Westheimer \& Kane, 2004; Biesta, 2011). Geboers, Geijsel, Admiraal, \& ten Dam (2013) have reviewed studies on effects of citizenship education. Even if they point out that studies of effectiveness are ambiguous, they conclude that an open, pedagogical classroom climate that has curriculum focus and which includes discussion and dialogue appears to be most effective in promoting citizenship in secondary school. Also Almgren (2006) who has analysed data from the international Civic Education Study (CivEd) conducted in 1999, concludes that deliberative classroom climate has a positive effect on students. However, Biesta criticizes the assumption that democratic learning, which he calls citizenship, 'can be understood as the outcome of an educational trajectory' (Biesta, 2011, p. 13). The overriding concern seems to be to 'find the "best" and most 'appropriate' methods and approaches of teaching citizenship to young people - of achieving what is regarded to be a common goal that they can aspire to' (Biesta, 2011, p. 13). Instead he considers citizenship to be a practice. 
Howe \& Abedin's review of empirical research on discussion and dialogue in primary and secondary school classrooms shows that 'classroom dialogue revolves around teacherstudent IRF, which is embellished in varying ways' (2013, p. 344). IRF, also known as IRE, is a communication structure in whole-class instruction that consists of teacher Initiation, student Response and teacher Feedback or teacher Evaluation (Cazden, 2001). Much of the research deals with distribution of student participation in dialogues according to gender and ethnicity. Howe \& Abedin distinguish between model-based assessment and target-based assessment of the dialogue, where the latter is mainly concerned with reaching the curriculum target. Research on model-based assessment consists of classroom discussion, contrasting viewpoints and talk characterised as exploratory. They conclude that 'teachers find it extremely difficult to promote exploratory talk in classrooms' (p. 341), probably because of the tension between freedom of exploring student views and the constraints arising from delivering on the curriculum goals.

Liljestrand (2002) has studied how education can contribute to the development of democratic citizens through teacher-led whole-class discussions in upper secondary school in Sweden. The study points out that the classroom discussion activities are co-constructed by the teachers and students. This means that discussions are not only an outcome of curriculum but also dependent on the social interaction in the classroom. Furthermore, the students in the study are more active in the classroom discussion when the issue is supposed to be known from their life world. It is in line with Biesta \& Säfström's (2001) argument in which they point out that this is as a necessary condition for getting students to actively participate in democratic classroom discussion: the issues have to be familiar to them from their own life and experiences. This fact is supported in many studies (Rubin, 2007). The connection to the students' life-world, their experiences and the cultural and societal questions that concern them, also connect the idea of democracy to Bildung (Klafki, 2001) and to meaningful teaching communication from a Bildung perspective when students contribute in conversational speech with diverse interpretations of subject matter (see Aasebø, Midtsundstad \& Willbergh, 2017).

Studies also show that students sometimes can be reluctant to express their opinions, particularly on controversial issues. Peer cultures and peer approval are important for what students can express in classrooms (Aasebø, 2011). King's (2009) study shows how students' fear of taking emotional and cognitive risks in classroom discussions often leads them to avoid participating in controversial discussions.

\section{Method}

The empirical data stems from qualitative classroom observation of whole-class teaching in lower secondary school (13-16-year-old students) in Norway. The data were collected primarily for the purpose of studying Bildung-centered didactics and students' opportunities to experience meaning in whole-class talk (Aasebø et al., 2017) which has been re-analysed to study classroom discussions. The initial study was carried out as a multiplecase study in four schools, and the data were collected by observation of 'teaching communication', interviews of the observed teachers and the headmasters, and focus group discussions with the teacher groups. Two schools from different municipalities in two counties were selected: county a) ranked high and county b) ranked low in performance. The two schools in each county were selected from municipalities which perform lower than statistically 'expected' and better than 'expected' after controlling for several typically influential demographic variables: Parents' level of education, mothers' employment and the number of single-parent families (Bakken, 2004; Frøseth, \& Sandberg 2011; Hassan, 2009). Two of the schools are situated in small cities/urban settlements while the other two are situated in rural areas. Each of the rural schools has one class per grade, while in the small 
cities each grade has 3 to 4 classes per grade. In addition, the primary school classrooms in the rural schools are located in the same school buildings as the lower secondary classrooms, while in the small cities, primary classrooms are in separate buildings from the lower secondary classrooms.

The classroom observations which are analysed in this article consist of eight teacher observations, two from each school ${ }^{1}$. The teachers were observed using whole-class lessons in academic subjects during the course of a week. The observation was conducted as nonparticipant observation. Fangen (2010) finds the classroom to be a context which can reduce the discomfort of the participants when they are being observed, as this often makes people feel uncomfortable and stressed, which in turn means that subjects under observation behave in an unusual manner. The formal and predetermined structures in the classroom may reduce this observer effect.

The observation is based on all conversations between teachers and students in wholeclass talk. The observation has an inductive device, and the observation data emerges from the recording of all the teachers' utterances related to the subject matter (instructions, information, explanations, comments, questions for and answers to student initiatives) and students' answers, questions and comments relating to the subject matter. Most of the talk has been recorded verbatim; handwritten in the field notes, and not by a tape-recorder, and has been type written at the end of the school-day. Some teacher's lectures and some students' activities (as reading out loud from a textbook) have been reported in summaries. The sequences during the lessons have been described (as introduction, presentation of subject matter, discussion, interruptions and so on). The observation material consists of 79 lessons (8 to 14 lessons per teacher with an average of 10 lessons per teacher). These observations occurred in each of the three grades in the lower secondary school, in the subjects of Mathematics, Norwegian, English, German, Science, Social Science and RLE (Religion, Philosophy and Ethic). There were more observations in Norwegian than in English and German, which closely followed the requirement of teaching hours in the national curriculum.

At first, the conversations in which students were invited to take part in and offer their opinions, statements and explored understandings, are considered to be classroom discussions. The classroom discussions have been analysed in terms of characteristics of the conversation and the way students are positioned in these conversations. Secondly, the classroom discussions and student positions are discussed in relation to their contribution to the subject matter.

\section{Analysis of classroom discussions and student positions}

According to Liljestrand (2002), cultural expectations about schooling and teaching limit possibilities for other forms of conversation. Knowledge and facts in this study are often reproduced according to the IRE or IRF structure, in line with Howe \& Abedin (2013) who claim that this structure appears to be the most dominating structure for whole-class lessons in classrooms. The IRE-structured teaching communication in the present data material means that the teacher asks questions, rewards right and correct wrong answers:

T: When did the Industrial Revolution begin?

S: 1750 or something

T: And where did it begin?

S: In England

T: Right, about 1750 .

T: John, I remember reading about the spinning jenny, what is it? 
S (John): Kind of machinery that spins by itself T: Right

The IRE structure has been characterised as a form of teaching communication with homogenous interpretation of content and conversational speech (Aasebø et al., 2017). Cazden calls this IRF/IRE communication structure of classroom discourse "the default option - doing what the system is set to do "naturally" unless someone makes a deliberative change' (2001, p. 31). This structure also refers to teachers telling their students what they expect them to know, which tasks they expect to be challenging and which ones they should find they are able to handle. The students are primarily offered the position of a reproducer of knowledge. However, Liljestrand's (2002) review on research literature on classroom conversation also finds other forms of conversation; open questions as well as the IRF structure. Even if IRE/IRF are often used as synonyms, Liljestrand claims that IRF (as defined by Evaldsson, Lindblad, Sahlström \& Bergvist (2001)) means follow-up and is an expansion of follow-up in a more general manner.

Positioning of students as reproducers of knowledge is sometimes changed when some of the teachers ask for and reward reflection, creativity, associativity and understanding. The form of teaching communication which gives possibilities for such qualities has been characterised as dialogic: a combination of varied interpretation of content and conversational speech (Aasebø et al., 2017). This means that some classes are also offered positions which give possibilities for making personal and autonomous efforts at adjusting, reflecting and contextualising knowledge.

While the IRE structure, with a strong emphasis on right or wrong answers, can hardly be considered as a practice in which students experience democratic communication, classroom discussions may give students possibilities to assume other positions, as well as to gain experience in democratic skills and values. Classroom discussion in this study is considered to be conversations in which students are invited to take part in and offer their opinions, statements and explored understandings. When classroom discussions occur in this study, almost half take place in the subject Norwegian (literature), the rest in RLE (Religion, Philosophy, Ethic), science and social science, and only one in mathematic. The classroom discussions vary in duration and number of participants. The data material contains 26 segments which have been characterised as classroom discussion, comprising short exchanges (two statements) to longer exchanges (about 50 statements). They comprise discussions that involve only a single statement from one student, discussions that involve more than one student giving parallel or alternative statements, and discussions that involve contrary or conflicting statements from different students.

The analysis of classroom discussion focuses on teachers' initiatives and responses in the classroom discussions. Dependent on teachers' way of responding to the statements, two different types of classroom discussions are identified which position students in different ways. The first one, a minimalistic discussion which means to state an opinion, positions students as 'poll respondents', while the second one, a deliberative discussion positions students as learning debaters. 


\section{Students positioned as 'poll respondents'}

Students and teachers often have a minimalistic conception of what classroom discussion is. 'The mere fact that students state their opinions in class (and feel free to do so) constitutes a discussion' (Avery, Levy \& Simmons, 2013, p. 107) for them, while researchers in classrooms are looking for multiple viewpoints, exchanges, arguments and defences, and seem to have a more substantive and deliberative idea of what makes a discussion.

Students can be considered to be positioned as 'poll respondents' when they are invited to contribute with their opinion or interpretation of the subject matter without being asked to reason the statement or without being encountered by other arguments. It is often carried out simply in connection with teachers' instructions when the teacher poses a single question to the students about their point of view. It often results in a one-statement opinion: a single statement from a student. As example, in one case the teacher reviews the students' homework about industrialisation by posing questions which require right answers. Then the teacher says that China will reach the level of the US in thirty years and asks the students if they think China should also be allowed to become a rich country. One student answers 'yes'. The teacher immediately goes on to talk about the market mechanism.

The one-statement opinion is sometimes expanded by several statements from more students or by a couple of new questions from the teacher. In the case below, the teacher has asked the students about their interpretation of lifestyle diseases.

T: Why is being overweight an issue?

S1: Because we're not so physically active

T: Yes. Why do we speak so much about it nowadays?

S2: Fast food

T: Fast food

S3: Driving cars

T: Driving cars. Something else?

S4: Computers

T: Computers. How many of you are sitting in front of the computer two hours a day? Some students put up their hands

$\mathrm{T}$ : How many do physical exercise every day?

Some students put up their hands

When the conversation opens for a plurality of statements, the students sometimes provide a variety of parallel statements (fast food, driving cars, computers). Sometimes the statements do not receive any comment at all which can make them into indifferent statements; not worth a wider comment. Sometimes the classroom discussion borrows the form of communication from the IRF-structure: The teacher confirms or evaluates students' statements by praising them, saying 'yes', nod or just repeat students' words.

Even if the conversation opens for a variety of statements, the conversation rattles on without dwelling on the students' statements. This rattling on of a conversation takes place in longer teaching sequences, serving as an introduction to subject matter or as follow-up activity. In the case below, the students have watched a film about Muslims in Norway.

T: What do you think? Did you learn anything?

Many students: Yes

S1: (not audible) 
T: That's what you think

S2: She could merely marry a Muslim

$\mathrm{T}$ : You find it silly. S3

S3: It's difficult for Muslim men to participate in kitchen work

$\mathrm{T}$ : Yes. There are some differences between Muslims. What was it about?

S4: Differences between religious and cultural Muslims

T: Yes. Other things you think about?

S5: They like to hug people

T: We also like that. I like hugging very much

S6: Like they don't eat

$\mathrm{T}$ : When do they not eat?

S7: Ramadan

$\mathrm{T}$ : They eat at sunset, when it is dark. Other comments?

(...)

T: What did you think about?

S8: Christmas Eve

T: Yes, right, nothing about her religion (: the wife in the movie was a Christian). It was peculiar. What did she say about that?

S9: It was not so important for her to raise her children as Christians, but it was important for him.

T: The same old story, not so important for her. Mixed marriages are unusual. Now, we have run out of time.

This conversation comprises short statements from students without reasoning, and equally ranked statements without letting them confront each other. Even when the statements are contradictory as in the case below (boring, liking), students are seldom asked to reason and their statements are not put up in a discussion which can explore the differences. The quantity of the students' voices and the point that they express something or other seem to be more important than what the voices actually express.

T: Start to read the story over again. What do you think, how do you like it? Discuss, what do you think?

S1: It is boring

$\mathrm{T}$ : Some more opinions?

S2: I liked it, it described a lot

$\mathrm{T}$ : Next question from me (etc.)

The conversation can contribute to the dialogic perspective which in socio-cultural theory is based on Bakhtin's idea of the dialogue in which meaning production and learning is regarded as an interactive process. The interactive process consists of a plurality of voices, from the past, from the contemporary moment and from the future, as opposed to the monologue which is considered to be an authoritarian statement (Igland \& Dysthe, 2001). Conversation like this often involves many students participating in the classroom talk. Possibly, the traditional Norwegian principle of equality in school and education (Hernes, 1974) is connected to student participation, which means getting as many of the students as possible to speak. Many teachers in this study mention plurality of student participation as a measure of successful teaching, which can also be said about the IRE-structured communication which is able to bring about a plurality of student voices ${ }^{2}$. 
Teacher's responses to students' statements in the case above are about confirming and assessing. While the teacher sometimes confirms the opinion ('yes', 'right'), she also confirms the point that students have an opinion in itself ('that's what you think', 'you find it silly'). When the teacher makes a student's statement more complete (as when the student says 'Christmas Eve' and the teacher explains 'Yes, right, nothing about her religion'), she tries to make the students' statement clear and understandable. Supporting students' legal rights and their psychological rights, as well as clarifying students' statements, can be considered to be important preconditions for students' participation in democratic conversations. This is about empowering people to comment, interpret and consider which has much in common with the liberal democracy position that emphasises individual rights and interests (competition democracy).

Plurality in the form of many student voices seems to be given priority over reasoning and being part of the same discussion. When discussion does not mean reasoning the threshold for offering statements is not so high for the students. This can be an important advantage for some of the students who would not have participated in the conversation if they also had to reason and argue. This underpins the point about students having a voice, in the same way as a Gallup poll. However, the form of discussion is limited when it comes to sensitive issues that can open for statements that are conflicting, controversial, provocative or unacceptable to some. Conflicting statements, as in a case when different students respond with 'boring' and 'exciting' when they express their opinion on a genre in fairy tales, can be treated in the same way as parallel statements as part of the plurality of voices. Or as in the case below, when the student opposes a teacher's use of metaphor, the statement is ignored instead of discussed.

T: I know that some girls are compared with 'The ugly Duckling'. Media has put it in this way; earlier she was like the ugly duckling and later she turned to be a swan.

S: But we are human beings, not animals.

$\mathrm{T}$ : Go on reading, anyone who hasn't red yet?

When the teacher perceives statements on sensitive topic to be provocative or unacceptable the conversation can be turned around and become authoritarian when it is not open for reasoning, as in the case about students' comments and opinions on the Muslim film.

T: Other comments?

S: Men regard girls with contempt

T: No!

S: But at the end of the movie they are not allowed to hug each other

$\mathrm{T}$ : Yes, this is true (laughing).

The student's statement 'men regard girls with contempt' is rejected by the teacher without any counter-argument, which means that the teacher has given a quite authoritarian reply. In this case the student does not immediately accept the teacher's authority. Instead she starts on her own initiative to give reasons for her statement, a reasoning which is about the Muslim prohibition against hugging people from the opposite sex, which leads the teacher to accept the student's reasoning ('yes, this is true'). In another case about equal rights between men and women, the teacher handles a possible sensitive statement simply by deviating or dodging the statement by shifting the focus. The students are asked if there are equal rights for men and women. 
$\mathrm{T}$ (female): Do men with the same education and length of service as me make more money than me?

T: No

T: That's right. But the average man earns more than the average woman

S: Muslims, women has not the same rights

$\mathrm{T}$ : But they have the right to vote.

Deviating or rejecting students' statements in sensitive topics restricts the 'poll respondent position' and tells students what is unacceptable at school. The students' opinions are hardly changed by restrictions and the possibility to deliberate and learn seems to be closed.

\section{Students positioned as learning debaters}

The rattling on conversation which positions students as 'poll respondents' seems to be far more prevalent in this study than conversation where students take part in joint discussion with others and need to reason and nuance their statement. However, there is a 'fuzzy' transition from the opening classroom discussion in the previous case about equal rights, when the students point out different facts which state the reason for the status of equal rights, to a joint discussion. There are few cases in the data material in which students are invited to take part in a joint classroom discussion and are challenged to explore, give reasons or defend their statements. The very few cases occur in classroom talk in 'Religion and Ethics' which particularly seems to offer some possibilities for students to give reasons to different statements when the teacher invites them into a classroom discussion on contemporary issues. The subject matter in the case below is the death penalty.

T: Who are we talking about.. S1?

S1: They have committed a crime and then I think it's right

$\mathrm{T}$ : In the countries that are practicing the death penalty.. yes they have committed a crime but do you think it's right?

S1: It's both right and wrong

$\mathrm{T}$ : Both right and wrong?

S1: If they have committed an awful crime then..

$\mathrm{T}$ : It depends on what they have committed?

In this case the teacher has proclaimed that they are going to talk about the death penalty and asks distinctly for students' opinions. The teacher underlines the point of opinion by repeating the question ('but do you think it's right'). When the student answers 'both right and wrong' the teacher forces the student to explore the utterance. Then the teacher seems to suggest a conclusion concerning the student's opinion ('it depends on what they have committed'), but it can also be interpreted as an invitation to further nuancing (what it depends on). In the initial phase it is obvious that the teacher wants students to participate in a discussion in which they present opinions and give reasons. The classroom discussion continues in the case below.

S2: I think it's wrong.. a person should be imprisoned instead of only disappearing when he or she has committed a terrible crime.. should be imprisoned

S3: In the United States.. the man who kidnapped three girls and kept them locked up was imprisoned for life .. he thought it was better to commit suicide

(..) 
S4: I think everybody should get a new chance, even if they have done stupid things

T: Do you mean that.. S4?

S4: Yes

$\mathrm{T}$ : Yes you are reflecting..S5?

(..)

S5: Death penalty.. then you are done once and for all.. as a prisoner you have to think about it all your life.. if you have killed 20 people you get a bad conscience

T: That's why you think the death penalty is too easy?

S5: Yes (you have to) think about the crime you have committed

S6: But there are some differences. I would never give ABB (: the Norwegian man who killed 77 people on 22 July 2011) a new chance.. but a person who committed a homicide without intent should get a new chance.. but not ABB.. he should be imprisoned for (..)

S7: The other prisoners could hate him.. he could be punished by the others.. mistreated or raped

T: I don't think he's allowed to be in contact with other people

S7: Yes punished by the others.. that's my opinion

This conversation gives the students possibilities to proffer their points of view in a joint classroom discussion and involves a plurality of student voices. Different opinions are presented, reasoned, supplemented or countered; from the penalty depending on the type of crime, to the interpretation of the death penalty not really being a penalty, to the alternative of being punished by fellow prisoners, and finally to the idea that human beings always should be given a new chance; depending on whether or not the homicide was committed by intent.

The classroom discussion gives a plurality of statement and constitutes the student groups' joint interpretation of the subject matter. The students participate with a meaningful message as part of the common interpretation, the statements are given worth, sometimes with a building block other students rely on; sometimes on an opinion other students contradict and give opposite statements to. According to Aasebø et al. (2017) different students' interpretations also may increase the other students' possibility to experience meaning even if not everyone participates in the discussion.

The frame of the classroom discussion is given by the teacher's preceding question about opinions, the repeat of the question, and the force to explore and nuance a diffuse statement. The classroom discussion proceeds in a conversational climate which encourages the participants to give different reasons to the discussion, sustained by the teacher's supporting utterances ('yes, you are reflecting', 'that's why you think the death penalty is too easy'). The teacher does not position herself as an authority over the opinions given; she positions herself as a chairperson of the discussion. It implies to challenge students through questions, repeat their utterances as a question, and pose new questions based on the students' statements. However, by adding facts about the topic the teacher also brings didactic purposes into the classroom discussion, as in the example when the teacher adds the fact that a given prisoner is isolated from other prisoners. Even if this fact immediately does not seem to change the student's opinion, such facts or questions are important as a potential manner to qualify the classroom discussion and develop students' statements.

The students are positioned as learning debaters; as debaters in a classroom discussion based on their own points of view on important ethical and political issues, and as learners as well when the teacher draws conclusions from their statements, corrects information, and 
credits them for their reasoning. The classroom discussion can be considered to be deliberative and have some similarities with the idea of school as a weak public space (Englund, 2013); an open dialogue within which different opinions and values have a prominent place (Englund, 2006). The different experiences and opinions can contribute to the development of each student's competence and stance taking, as well as their understanding of other individuals' statements. In the case above, the students' voices have consequences for the classroom discussion and the way it plays out, but the process is dependent on teacher's direction by her comments, facts, questioning and perhaps also her oral rewards. The purpose of the classroom discussion is not to reach a joint or shared solution. Englund (2006) claims that the difference between deliberative democracy and deliberative communication is about the connection to decision-making. Deliberative democracy is closely connected to formal decision-making processes while deliberative communication is not, even though the difference is more about degree and not a clear distinction. The possibility of affecting other students' opinions in the sense of modifying, convincing, exploring and making all these kinds of changes that ordinarily occur when individuals are participating in a common discussion, are present, as is the opportunity to formulate and reformulate statements and in this way develop the students' communicative capabilities. In the present study the number of participating students is more limited compared to the minimalistic classroom discussions. However, the participants in the classroom discussions which have been interpreted as deliberative do not either involve teachers and students from different cultures, which is important to Englund (2013), not least due to the ongoing societal changes towards a more heterogeneous and multicultural society.

\section{Discussion and conclusion}

According to the dominating differences between the deliberative and liberal tradition of democracy the liberal or voting-centred view of democracy can be considered 'as an arena where fixed preferences and interests compete via (hopefully) fair mechanism of aggregation, (while) deliberative democracy instead emphasises the communicative process of willformation that precedes voting' (Samuelsson \& Bøyum 2015, p. 76 ). The question to discuss is how the two different classroom discussions can contribute to students' experiences of democracy. From a teaching perspective both will break up the teacher's monologue and have the possibility of introducing a more diverse interpretation into the knowledge. The teacher's talk (or the textbook's) are expanded by students' voices which together constitute the common 'container' of diverse opinions and interpretations of the subject matter in the wholeclass talk, in which the individual student can construct and negotiate her own opinion and interpretation. Friends and classmates - the coevals who are considered to be important for individual's construction of identity (Aasebø, 2011), will probably be important for the individuals' construction of knowledge as well (Aasebø et al., 2017).

The difference between fixed preferences versus will-formulation is in the theory of citizenship mentioned as 'enlightened citizens' ('already been') and 'citizens to be' (or 'still not'). Liljestrand (2002) has identified different classroom discussions according to these two concepts and claims that the position as 'already been' to a certain degree is an assumption for the classroom discussion. The students' 'poll position' in the current study can be identified according to the concept of 'already been'. The 'poll position' represents a democratic climate in the classroom in which students are allowed and encouraged to give their opinions and interpretations. Freedom of speech is encouraged, sustained and even developed by teachers. But an important question to pose is whether students' statements challenge or change the perception of what knowledge is about and what counts as valuable knowledge in school; in 
other words if the democratic climate makes knowledge more democratic, and less authoritarian.

From a Bildung perspective on knowledge Gustavsson (2001) regards interpretation and understanding as a connection between the familiar and the unknown. Dialogue means that individuals open up for other interpretations and their own understanding is challenged in order to gain a better understanding of the issue being discussed. The dialogue and exchanges continuously change the individuals' interpretations. The 'poll position' is not a part of a dialogue that intends 'becoming'; that is - possibilities for challenges or changes. Neither does the 'poll position' encourage what counts as valuable knowledge in school, because the speaking is more important than what is said. The content, the attitudes or the opinions are basically treated with indifference, or at least they are not supported, developed or countered. Students' opinions and interpretations are not challenged in ways where one can assume they have a 'formative potential' to use concepts from Bildung theory (Westbury, 2000). Freedom to speak and to give opinions is a democratic right; but as long as the statements are not encountered as statements worth discussion, the valuable knowledge remains unchanged. Students' statements seem to be a welcome variation in whole class talk for students as well as teachers. But the lack of giving the students' statements sense in relation to knowledge leaves those statements as nothing more than a break in the conversation. It implies that the position as 'already been' from a democratic point of view does not correspond with similar student positions related to knowledge and that democratic participation attains status as a diversion from the real work at school.

On the other side the idea of schooling has traditionally positions students as 'still not'. The 'still not' position undermines students' preconceptions and current interpretations of the issue being discussed and constrains the possibilities for the students' participation. At this the 'poll position' reflects that students are perceived as more than learners in school and that the school appreciates students' active participation and acknowledges students' attitudes, viewpoint and experiences.

Liljestrand (2002) make an important point when he claims that the two concepts 'already been' and 'still not' can be considered as a changing continuum, where students' positions vary in different classroom discussions. But in relation with knowledge the dualism of the two positions means that students' participation is detached from knowledge transmission or knowledge construction. When students are positioned as learning debaters in the current study, they are neither positioned as 'already been' nor as 'still not' but rather as a fusion of being and becoming, a fusion which exceeds the binary contradiction between the two concepts. The classroom discussion is not based solely on students' deliberative participation, teachers' didactic position is important as well when she contributes with factual knowledge as well as when she directs the discussion. Probably it supports Englund's (2006) assertion that knowledge transmission and deliberative communication are able to mutually enrich each other instead of being a contradiction. When the teacher brings factual knowledge into the conversation it does not mean that knowledge has a status as an authority which concludes the classroom discussion. It is also a means that can explore students' reasoning.

A problem with the 'poll position' are related to the moral dimension of knowledge when it comes to sensitive issues. In some classroom discussions the democratic and equality based idea of participation are limited and constrained by teachers. When the teacher denies the student's statements about Muslim men's derogatory view on women, she denies the student's observation, but does not argue against it. The student, on her own initiative, 
explains her statement by adding an observation about hugging, an explanation which seems to be an acceptable statement for the teacher. The discussion about the Muslim view on women is basically finished and put aside. The fact about hugging is accepted, not the statements about men's derogatory view on woman. The 'poll position' makes it possible for students to utter statements that teachers find inappropriate or unacceptable. The case demonstrates that teacher's determination of acceptable and unacceptable statements undermines students 'poll position' when it comes to controversial and sensitive issues. Opinions that exist among students are prevented from being discussed and refuted in an open dialogue where prejudices and unacceptable arguments, could be countered and eradicated (Englund, 2013). Finally, it confirms the idea of school's knowledge as non-democratic and 'fixed' without relationships to students' previous interpretations and experiences.

Probably, the 'poll position' reflects the Scandinavian tradition of less authoritarian and more symmetric and informal relations between teachers and students, described as the school's aura (Ziehe, 1989) or a school culture mentioned as a 'home' (Lieberkind, (2015). The International Civic and Citizenships Educational Study (ICCS) shows that Scandinavian students report a high degree of 'openness in classroom discussions' (Lieberkind, 2015, p. 718). The questions in the survey deal with how often students can freely express meanings and can frankly disagree with the teacher, and how often teachers encourage students to discuss, form and present their opinions, how often students raise a current political issue, and if teachers present diverse aspects of an issue (Mikkelsen, 2011). Paradoxically the students' perception of the democratic classroom context does not result in high scores on their external citizenship efficacy and internal political efficacy (Lieberkind, 2015). The openness in classroom discussions in ICCS can very well fit the 'poll position' in the current study. Openness or participation does not necessarily mean a classroom culture in which students are positioned as contributors to knowledge or the subject matter, if their expressions and statements are not given sense as part of the knowledge construction in which statements are developed, supported and countered.

To conclude, the dominating 'poll position' in classroom discussions gives students possibilities for participation which is a necessary basis for all democratic activities. It can support students' legal rights to have an opinion and strengthen the psychological attitude of being individuated. It can be an important part of the learning process where personal attitudes and experiences spice up the subject matter. But it does not mean that students have influenced anything. It means that students' opinions are welcomed but not interpreted, extended, developed, challenged, or reasoned. It consolidates the nature of knowledge as being transferred and reproduced, not constructed by prior and new understanding. When the "poll position" dominates the way of positioning students in classroom discussions, students are rather presented with the illusion of democracy.

If we consider democracy to finally be a question about how to consider and comprehend the character of knowledge, democracy can be challenged and even oppressed by other educational political concerns such as an increasing standardised test focus in school connected to knowledge achievement and outcome. According to Lieberkind (2015) there has been a change in the Scandinavian tradition of democratic education and democratic pedagogy from the 1970/80s in favour of knowledge performance. The minimalistic comprehension of democracy as students" "poll position" in teaching will obviously make it easier for teachers to overcome the schism between aims of democracy and standardised learning outcome. 
The test focus obviously affects the way knowledge is handled in schools. A more demanding question to pose, however, is whether test focus can easily override democratic classroom practice just because the strongest shared view of knowledge put into practice in school always has implied a division between democratic participation and knowledge, even in the heyday of reform pedagogy and dialogical pedagogy. Possibilities for students' democratic practice in school seem basically to be a question about what counts as knowledge and whose knowledge counts.

\section{References}

Aasebø, T. (2011). Anti-schoolness in context: The tension between the youth project and the qualification project. Social Psychology of Education, 14, 503-518. DOI: http://link.springer.com/article/10.1007/s11218-011-9153-3

Aasebø, T. S., Midtsundstad, J., \& Willbergh, I. (2017). Teaching in the age of accountability: restrained by school culture?". Journal of Curriculum Studies, 49(3), 273-290.

DOI: http://www.tandfonline.com/doi/full/10.1080/00220272.2015.1072249

Almgren, E. (2006). Att fostra demokrater: Om skolan i demokratin och demokratin $i$ skola. Uppsala: Acta Universitatis Upsaliensis.

Avery, G., Levy, S.A., \& Simmons, A.M.M. (2013). Deliberating controversial public issues as part of civic education. The Social Studies, 104, 105-114. DOI: http://www.tandfonline.com/doi/pdf/10.1080/00377996.2012.691571

Biesta, G. J. J. (2011). Learning Democracy in School and Society: Education, Lifelong Learning, and the Politics of Citizenship. Rotterdam: Sense Publishers.

Biesta, G., \& Säfström, C.-A. (2001). Learning democracy in a world of difference. The School Field, 12(5/6), 61-72.

Buckingham, D. (2000). After the death of childhood: Growing up in the age of electronic media. Cambridge, UK: Polity Press.

Burr, V. (2003). Social constructionism. London: Routledge.

Cazden, C. B. (2001). Classroom discourse: The language of teaching and learning. Portsmouth, NH: Heinemann.

Ekman, J. (2011). Skolan och medborgarskapandet. En kunskapsöversikt. Stockholm: Elanders.

Englund, T. (2006). Deliberative communication: A pragmatist proposal. Journal of Curriculum Studies, 38(5), 503-520. DOI: http://www.tandfonline.com/doi/abs /10.1080/00220270600670775

Englund, T. (2013). Aktuella perspektiv på skolans medborgerliga skapande. In N. Hartsmar, \& B. Liljefors-Persson (Eds.), Medborgerlig bildning: demokrati och inkludering för ett hållbart samhälle (pp. 35-64). Lund, Studentlitteratur.

Eriksen, E. O., \& Weigård, J. (1999). Kommunikativ handling og deliberativt demokrati: Jürgen Habermas' teori om politikk og samfunn. Bergen: Fagbokforlaget.

Evaldsson, A.-C., Lindblad, S., Sahlström, F., \& Bergquist, K. (2001). Introduktion och forskningsöversikt. In S. Lindblad, F. Sahlström, \& K.-G. Ahlström (Eds.), Interaktion i pedagogiska sammanhang (pp. 9-35). Stockholm: Liber.

Fangen, K. ( 2010). Deltagende observasjon. Bergen: Fagbokforlaget.

Fine, M. (1993). 'You can't say that the only ones who can speak are those who agree with your position': Political discourses in the classsrom. Harvard Educational Review, 63 (4),412-433.DOI:http://hepgjournals.org/doi/pdf/10.17763/haer.63.4.504 $\underline{\mathrm{mp} 416 \mathrm{q} 4 \mathrm{k} 30446}$

Fjellstad, R. (2011). Elevene og skolen. Norsk hovudrapport frå demokratiundersøkinga (pp. 97-124). Universitetet i Oslo/ILS. Retrieved from http://www.udir.no/globalassets/upload/rapporter/iccs-rapport/5/iccs-rapport.pdf 
Geboers, E., Geijsel, F., Admiraal, W., \& ten Dam, G. (2013). Review of the effects of citizenship Education. Educational Research Review, 9, 158-173. DOI: http://www.sciencedirect.com/science/article/pii/S1747938X12000176

Grant, R.W. (1996). The Ethics of Talk: Classroom conversation and democratic politics. Teachers College Record, 97(3), 470-482.

Gustavsson, B. (2001). Vidensfilosofi. Århus: Klim.

Harber, C. (1997). International Developments and the Rise of Education for Democracy. Compare, 27(2), 179-191. DOI:http://www.tandfonline.com/doi/abs/10.1080/0305 792970270205

Habermas, J. (1996). Between Facts and Norms: Contributions to a Discourse Theory of Law And Democracy. Cambridge, MA: MIT Press.

Hernes, G. (1974): Om ulikhetens reproduksjon - hvilken rolle spiller skolen? In M. S. Mortensen (Ed.), I forskningens lys. 32 artikler om norsk forskning i går, i dag, $i$ morgen. Oslo: NAVF.

Howe, C., \& Abedin, M. (2013). Classroom dialogue: A systematic review across four decades of research. Cambridge Journal of Education, 43(3), 325-356. DOI: http://www.tandfonline.com/doi/abs/10.1080/0305764X.2013.786024

Igland, M.-A., \& Dysthe, O. (2001). Mikhail Bakhtin og sosiokulturell teori. In O. Dysthe (Ed.), Dialog, samspel og loering (pp. 107-127). Oslo: Abstrakt forlag.

King, J. T. (2009). Teaching and Learning about Controversial Issues: Lessons from Northern Ireland. Theory \& Research in Social Education, 37(2), 215-246. DOI:http://www.tandf online.com/doi/abs/10.1080/00933104.2009.10473395

Klafki, W. (2001). Dannelsesteori og didaktik - nye studier. Århus: Forlaget Klim.

Lieberkind, J. (2015). Democratic Experience and the Democratic Challenge: A Historical and Comparative Citizenship Education Study of Scandinavian Schools. Scandinavian Journal of Education, 59(6), 710-730. DOI:http://www.tandfonline.com/doi/abs/10. $\underline{1080 / 00313831.2014 .971862}$

Liljestrand. J. (2002). Klassrummet som diskussionsarena. Örebro Universitet: Örebro Studies in Education, 6.

Meld. St. 20 (2015-2016). Fag-fornying - forståelse. En fornyelse av kunnskapsløftet. Oslo: Kunnskapsdepartementet.

Oppenheim, A. (1975). Civic Education in Ten Countries. New York, NY: Wiley.

Rubin, B. C. (2007). 'Laboratories of democracy'. A Situated Perspective on Learning Social Studies in Detracted Classrooms. Theory \& Research in Social Education, 1, 62-95. DOI: http://www.tandfonline.com/doi/abs/10.1080/00933104.2007.10473326

Samuelsson, M., \& Bøyum, S. ( 2015). Education for deliberative democracy: Mapping the field. Utbildning \& Demokrati, 24(1), 75-94. DOI:https://bora.uib.no/handle/1956/ $\underline{12487}$

Solhaug, T., \& Børhaug, K. (2012). Skolen i demokratiet - demokratiet i skolen. Oslo: Universitetsforlaget.

Stray, J.H. (2012). Demokratipedagogikk. In K.L. Berge, \& J. H. Stray (Eds.), Demokratisk medborgerskap i skolen (pp. 17-33). Bergen: Fagbokforlaget

Westbury, I. (2000). Teaching as a Reflective Practice: What Might Didaktik Teach Curriculum? In Westbury, I., Hopmann, S. T., \& Riquarts, K. (Eds.), Teaching as a reflective practice: German didaktik tradition (pp. 15-39). Mahwah, N.J.: L. Erlbaum Associates.

Westheimer, J., \& Kahne, J. (2004). What Kind of Citizen? The politics of education. The American Educational Research Journal, 41(2), 1-30. DOI:http://aer.sagepub.com /content/41/2/237 
Aasebø (2017). Education Reform Journal, 2017, 2(1), 1-16

Ziehe, T. (1989). Kulturanalyser: Ungdom, utbildning, modernitet. Stockholm/Stehag: Symposium Bokförlag.

\section{Notes}

${ }^{1}$ The interviews and focus group discussions are not used as data material in this paper, except for one statement emphasized by many teachers about plurality of student participation, that is referred to in the analysis.

${ }^{2}$ Se end note 1 . 